\title{
Ozone disinfection for viruses with applications in healthcare environments: a scoping review
}

\author{
Milena Suemi IRIE(a) \\ Lia DIETRICH(b) iD \\ Gabriela Leite de SOUZA(c) \\ Priscilla Barbosa Ferreira \\ SOARES(a) iD \\ Camilla Christian Gomes \\ MOURA $^{(c)}$ iD \\ Gisele Rodrigues da SILVA(d) \\ Luiz Renato PARANHOS(e)
}

(a) Universidade Federal de Uberlândia UFU, School of Dentistry, Department of Periodontology and Implantology, Uberlândia, MG, Brazil.

(b) Universidade Federal dos Vales do Jequitinhonha e Mucuri - UFVJM, School of Dentistry, Department of Dentistry, Dental Prosthesis, Diamantina, MG, Brazil

(c) Universidade Federal de Uberlândia UFU, School of Dentistry, Department of Endodontics, Uberlândia, MG, Brazil.

(d) Universidade Federal de Uberlândia - UFU, Department of Operative Dentistry and Dental Materials, Uberlândia, MG, Brazil.

(e) Universidade Federal de Uberlândia UFU, School of Dentistry, Department of Community and Preventive Dentistry, Uberlândia, MG, Brazil.

Declaration of Interests: The authors certify that they have no commercial or associative interest that represents a conflict of interest in connection with the manuscript.

\section{Corresponding Author:}

Luiz Renato Paranhos

paranhos.Irp@gmail.com

hitps://doi.org/10.1590/1807-3107bor-2022.vol36.0006

Submitted: February 6202

Accepted for publication: July 13, 2021

Last revision: August 18, 2021
Abstract: The aim of this scoping review was to provide sufficient information about the effectiveness of ozone gas in virus inactivation of surfaces and objects under different environmental conditions. The review was performed according to the list of PRISMA SrC recommendations and the JBI Manual for Evidence Synthesis for Scoping Reviews. The review was registered in Open Science Framework (OSF). EMBASE (Ovid), Lilacs, LIVIVO, MEDLINE (PubMed), SciELO, Scopus and Web of Science were primary sources, and "gray literature" was searched in OpenGray and OpenThesis. A study was included if it reported primary data on the effect of ozone gas application for vehicle-borne and airborne virus inactivation. No language or publication date restriction was applied. The search was conduct on July 1, 2020. A total of 16,120 studies were screened, and after exclusion of noneligible studies, fifteen studies fulfilled all selection criteria. Application of ozone gas varied in terms of concentration, ozone exposure period and the devices used to generate ozone gas. Twelve studies showed positive results for inactivation of different virus types, including bacteriophages, SARS-CoV-2 surrogates and other vehicleborne viruses. Most of the studies were classified as unclear regarding sponsorship status. Although most of the population has not yet been vaccinated against COVID-19, disinfection of environments, surfaces, and objects is an essential prevention strategy to control the spread of this disease. The results of this Scoping Review demonstrate that ozone gas is promising for viral disinfection of surfaces.

Keywords: Disinfection; Ozone; Virus Inactivation.

\section{Introduction}

SARS-CoV-2 spread from China worldwide in less than 4 months, directly impacting the economy, health and lifestyle of affected countries. Transmission can occur via human-to-human contact, contact with infected surfaces (fomites or skin-to-skin), or airborne transmission, which occurs through the mouth, nose, and eyes or through inhalation of small respiratory droplets suspended in the air., ${ }^{1,2}$

There is currently no approved and effective antiviral treatment against SARS-CoV-2, ${ }^{1,3}$ and ongoing COVID-19 vaccination programs have not reached most of the population; thus, prevention remains the main strategy 
for controlling the spread of the disease. However, considering the difficulty in directly conducting research with SARS-CoV-2, which requires biosafety level 3 (BSL3) or higher, many studies using surrogate viruses have been conducted to develop methods to prevent SARS-CoV-2 infection. ${ }^{4}$ Hence, efforts have focused on disinfection of environments and objects as well as individual protection and preventative measures to avoid disease spread and potential outbreaks. ${ }^{1}$ Aerosol, droplet, and fomite transmission are important routes for the spread of many viral diseases. ${ }^{5}$ Among the numerous disinfection and sanitization methods proposed, ${ }^{6}$ devices that generate ozone are commonly applied due to the ability of gaseous ozone to easily penetrate into all areas of a room, furniture and other objects. ${ }^{7}$

Ozone is a gas that forms chemically via an unstable triatomic molecule of oxygen $\left(\mathrm{O}_{3}\right)$ that it quickly degrades to its stable state (diatomic oxygen), ${ }^{8}$ leading to formation of secondary oxidants (hydroxyl radicals) with high reactivity and a short reaction time. ${ }^{9,10}$ In brief, the disinfection mechanism is based on the reaction of ozone with organic compounds containing double bonds. ${ }^{11}$ Virus inactivation occurs as a consequence of envelope protein denaturation, impairing virus adhesion to cells, oxidation of unsaturated fatty acids present in the lipid envelope, and destruction of single-stranded RNA. ${ }^{7}$ However, the effectiveness of ozone as a virucide is related to various factors, including the ozone concentration,, 812 exposure time, ${ }^{8}$ and temperature ${ }^{8,12,13}$ and relative humidity of the environment. ${ }^{12,13}$

In the current pandemic of SARS-CoV-2, identifying a disinfection process that interrupts virus transmission routes, including contaminated surfaces, is of utmost importance. Therefore, the present scoping review aims to provide sufficient information about the effectiveness of ozone gas for inactivation of vehicle-borne and airborne viruses under different environmental conditions.

\section{Methodology}

\section{Protocol registration}

The scoping review protocol was performed according to Preferred Reporting Items for Systematic
Review and Meta-Analysis Protocols (PRISMA-P) ${ }^{14}$ and was registered in Open Science Framework (https:// osf.io/2a3nu/ - DOI 10.17605/OSF.IO/2A3NU). This review is reported following Preferred Reporting Items for Systematic Review and Meta-Analysis (PRISMA) guidelines - extension for scoping review ${ }^{15}$ and was conducted according to Joanna Briggs Institute Critical Appraisal tools in JBI Manual for Evidence Synthesis for Scoping Reviews ${ }^{16}$. The Arksey and O'Malley methodological framework ${ }^{17}$ was employed to conduct this scoping review: a) identifying the research question, b) identifying relevant studies, c) study selection, d) data charting process and e) summarizing and reporting results.

\section{Research question and eligibility criteria}

Eligibility criteria were based on the following research question: "Is there evidence of the effectiveness of the application of ozone gas in inactivating vehicle borne and airborne viruses with applications to healthcare environments"? The "PCC" (Population, Concept, and Context) mnemonic was used to guide this scoping review, where $\mathrm{P}$ denotes vehicle borne and airborne viruses, $\mathrm{C}$ ozone disinfection, and $\mathrm{C}$ reducing surface transmission.

\section{Inclusion criteria}

A study was eligible for inclusion if it reported primary data on the effect of ozone gas application on inactivation of vehicle-borne (blood, fluids and fomites) and airborne viruses. No language or publication date restriction was applied. In vitro studies, clinical trials, and experimental and observational studies (prospective and retrospective) were included.

\section{Exclusion criteria}

Exclusion criteria were as follows: a) studies involving virus inactivation in water for sewage treatment; b) studies involving food and agriculture; c) studies using ozone application as a coadjuvant method for virus inactivation or studies in which ozone was a byproduct from a different decontamination system (not gas); d) case reports and case series; e) systematic reviews; f) conference abstracts, letters, and editorials; and g) personal opinions and books and/or book chapters. 


\section{Literature search and study selection}

The following databases were searched on July 1, 2020: MEDLINE (PubMed), Scopus, EMBASE, Lilacs, LIVIVO, SciELO, and Web of Science. Part of the "gray literature" was searched in OpenGray and OpenThesis. Descriptors were selected using Medical Subject Headings (MeSH), Descriptors in Health Science (DeCS), and Embase Subject Headings
(Emtree). Boolean operators (AND and OR) were used to combine descriptors and improve the search strategy by means of different combinations (Table 1). The search strategy for MEDLINE was adapted for the other databases, respecting their rules of syntax.

The results obtained from the primary databases were initially exported to EndNote Web ${ }^{\mathrm{TM}}$ (Clarivate ${ }^{\mathrm{TM}}$, Analytics, Philadelphia, USA), excluding duplicates.

Table 1. Strategies for database searches.

\begin{tabular}{|c|c|}
\hline Database & Search strategy (July 2020) \\
\hline Embase (http://www.embase.com) & $\begin{array}{l}\text { ('ozone' OR 'ozonotherapy' OR 'ozone therapy' OR 'o3' OR 'ozonized') AND ('disinfection' OR } \\
\text { 'infection control' OR 'prevention and control' OR 'biological control agents' OR 'disease transmission' } \\
\text { OR 'safety management' OR 'personal management' OR 'disinfectant' OR 'decontamination' OR 'ppe' } \\
\text { OR 'virus inactivation' OR 'airborne transmission' OR 'healthcare workers') NOT ('food' OR 'agriculture' } \\
\text { OR 'drinking water') }\end{array}$ \\
\hline LILACS (http://lilacs.bvsalud.org/) & $\begin{array}{c}\text { (("Ozone" OR "Ozonotherapy" OR "Ozone Therapy" OR "O3" OR "Ozonized") AND ("Disinfection" } \\
\text { OR "Infection Control" OR "Prevention and Control" OR "Biological Control Agents" OR } \\
\text { "Disease Transmission" OR "Safety Management" OR "Personal Management" OR "Disinfectant" } \\
\text { OR "Decontamination" OR "PPE" OR "Virus Inactivation" OR "Airborne Transmission" OR } \\
\text { "Healthcare Workers")) }\end{array}$ \\
\hline LIVIVO (http://livivo.de) & $\begin{array}{l}\text { (("Ozone" OR "Ozonotherapy" OR "Ozone Therapy" OR "O3" OR "Ozonized") AND ("Disinfection" } \\
\text { OR "Infection Control" OR "Prevention and Control" OR "Biological Control Agents" OR "Disease } \\
\text { Transmission" OR "Safety Management" OR "Personal Management" OR "Disinfectant" OR } \\
\text { "Decontamination" OR "PPE" OR "Virus Inactivation" OR "Airborne Transmission" OR "Healthcare } \\
\text { Workers") NOT ("Food" OR "Agriculture" OR "Drinking Water")) }\end{array}$ \\
\hline $\begin{array}{l}\text { PubMed (http://www.ncbi.nlm.nih. } \\
\text { gov/pubmed) }\end{array}$ & $\begin{array}{c}\text { (("Ozone" OR "Ozonotherapy" OR "Ozone Therapy" OR "O3" OR "Ozonized") AND ("Disinfection" } \\
\text { OR "Infection Control" OR "Prevention and Control" OR "Biological Control Agents" OR "Disease } \\
\text { Transmission" OR "Safety Management" OR "Personal Management" OR "Disinfectant" OR } \\
\text { "Decontamination" OR "PPE" OR "Virus Inactivation" OR "Airborne Transmission" OR "Healthcare } \\
\text { Workers") NOT ("Food" OR "Agriculture" OR "Drinking Water")) }\end{array}$ \\
\hline SciELO (http://www.scielo.org/) & $\begin{array}{c}\text { (("Ozone" OR "Ozonotherapy" OR "Ozone Therapy" OR "O3" OR "Ozonized") AND ("Disinfection" } \\
\text { OR "Infection Control" OR "Prevention and Control" OR "Biological Control Agents" OR } \\
\text { "Disease Transmission" OR "Safety Management" OR "Personal Management" OR "Disinfectant" } \\
\text { OR "Decontamination" OR "PPE" OR "Virus Inactivation" OR "Airborne Transmission" OR } \\
\text { "Healthcare Workers")) }\end{array}$ \\
\hline Scopus (http://www.scopus.com/) & $\begin{array}{c}\text { (("Ozone" OR "Ozonotherapy" OR "Ozone Therapy" OR "O3" OR "Ozonized") AND ("Disinfection" } \\
\text { OR "Infection Control" OR "Prevention and Control" OR "Biological Control Agents" OR } \\
\text { "Disease Transmission" OR "Safety Management")) } \\
\text { (("Ozone" OR "Ozonotherapy" OR "Ozone Therapy" OR "O3" OR "Ozonized") AND ("Personal } \\
\text { Management" OR "Disinfectant" OR "Decontamination" OR "PPE" OR "Virus Inactivation" OR } \\
\text { "Airborne Transmission" OR "Healthcare Workers")) }\end{array}$ \\
\hline $\begin{array}{l}\text { Web of Science } \\
\text { (http://apps.webofknowledge.com/) }\end{array}$ & $\begin{array}{l}\text { (("Ozone" OR "Ozonotherapy" OR "Ozone Therapy" OR "O3" OR "Ozonized") AND ("Disinfection" } \\
\text { OR "Infection Control" OR "Prevention and Control" OR "Biological Control Agents" OR } \\
\text { "Disease Transmission" OR "Safety Management" OR "Personal Management" OR "Disinfectant" } \\
\text { OR "Decontamination" OR "PPE" OR "Virus Inactivation" OR "Airborne Transmission" OR } \\
\text { "Healthcare Workers") NOT ("Food" OR "Agriculture" OR "Drinking Water")) }\end{array}$ \\
\hline $\begin{array}{l}\text { OpenGrey } \\
\text { (http://www.opengrey.eu/) }\end{array}$ & $\begin{array}{c}\text { (("Ozone" OR "Ozonotherapy" OR "Ozone Therapy" OR "O3" OR "Ozonized") AND ("Disinfection" } \\
\text { OR "Infection Control" OR "Prevention and Control" OR "Biological Control Agents" OR } \\
\text { "Disease Transmission" OR "Safety Management" OR "Personal Management" OR "Disinfectant" } \\
\text { OR "Decontamination" OR "PPE" OR "Virus Inactivation" OR "Airborne Transmission" OR } \\
\text { "Healthcare Workers")) }\end{array}$ \\
\hline $\begin{array}{l}\text { OpenThesis } \\
\text { (http://www.openthesis.org/) }\end{array}$ & $\begin{array}{l}\text { (("Ozone" OR "Ozonotherapy" OR "Ozone Therapy" OR "O3" OR "Ozonized") AND ("Disinfection" } \\
\text { OR "Infection Control" OR "Prevention and Control" OR "Biological Control Agents" OR } \\
\text { "Disease Transmission" OR "Safety Management" OR "Personal Management" OR “Disinfectant" OR } \\
\text { "Decontamination")) }\end{array}$ \\
\hline
\end{tabular}


The remaining references retrieved from OpenGray and OpenThesis were exported to Microsoft Word ${ }^{\mathrm{TM}}$ 2019 (Microsoft $^{\mathrm{TM}}$ Ltd., Washington, USA) software, and duplicates were manually removed. The reviewers (MSI and GSL) independently performed a methodical analysis of all study titles, specifically evaluating the study design and excluding those that did not meet the inclusion criteria. When reading abstracts, all eligibility criteria were taken into account. The complete texts were read, and possible disagreements were resolved by a third reviewer (LD). In cases where the title or abstract provided insufficient information to accomplish a proper inclusion or exclusion decision, the full text was read to address any doubts. The references of the eligible studies were evaluated as well as those identified by experts in the field. These strategies were performed to minimize selection and publication bias.

\section{Data charting process and data items}

After study selection, the reviewers performed a calibration exercise that consisted of selecting and extracting data from three randomly selected articles. The studies were analyzed independently by two reviewers (MSI and GLS). All of the data were checked by another author. The following information was extracted: meta data (author, date, year of publication), virus type, treatment groups, virus carrier/contact surface, method of assessing virus inactivation, ozonation method, device, ozone concentration (ppm), $\mathrm{pH}$, temperature, relative humidity $(\mathrm{RH})$, exposure time to ozone and key findings.

\section{Sponsorship status evaluation}

Information regarding the source of funding of the selected studies was also assessed. These data were extracted because industry sponsorship might be associated with risks of publication, reporting and selection biases. ${ }^{18}$ The sponsorship status was classified as follows: ${ }^{19}$

a. Unclear - when it was not possible to affirm the sponsorship status even after an attempt to contact the authors by email;

b. Nonsponsored - when the authors declared that the study did not receive any type of financial support from companies related to ozone-generating devices; c. Sponsored - when the authors reported any financial contribution (financial support, provision of equipment or supplies, discounts, etc.) from companies related to ozonegenerating devices.

The main text and acknowledgments were checked to collect this information. In cases of missing information or unclear data, the authors were contacted twice by e-mail at an interval of one week.

\section{Synthesis of results}

The results of eligible studies were summarized in a descriptive/narrative manner, including study characteristics, and virus inactivation efficiency of interest relative to the healthcare environment was synthesized. Studies reporting ozone concentrations expressed in $\mathrm{mg} / \mathrm{L}$ were transformed to part per million (ppm) for analysis.

\section{Results}

\section{Selection of evidence sources}

During the first phase of study selection, 16,120 results among nine electronic databases, including the gray literature, were obtained. After removing repeated/duplicate results, 9937 articles remained for analysis of titles and abstracts. After detailed analysis, only 59 studies were eligible for full-text analysis. One study was included as an expert suggestion. The references of the potentially eligible studies were evaluated carefully, and one additional article was selected, resulting in 61 studies for full-text assessment. After reading the full text, studies that did not fulfill the inclusion criteria were eliminated. Ultimately, 15 studies were included in the scoping review. Figure 1 illustrates the search process, identification, inclusion and exclusion of eligible studies.

\section{Characteristics of evidence sources}

\section{Overview}

The studies included were published between 1990 and 2020, and most were performed in North America (46.6\%) (Figure 2). These studies analyzed the effectiveness of ozone application using different study designs. Most tested the effectiveness of ozone 

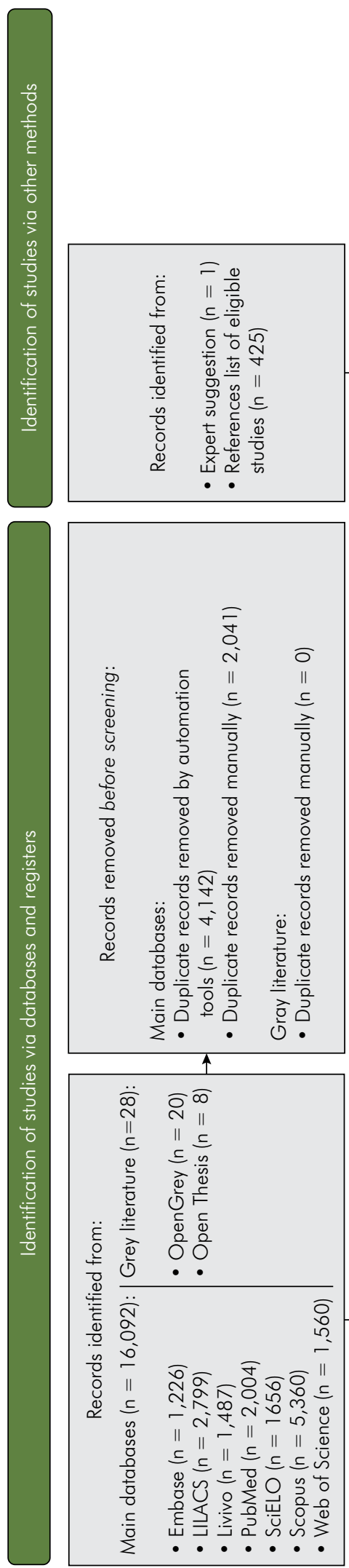

ио!!рว!!!+นәр!

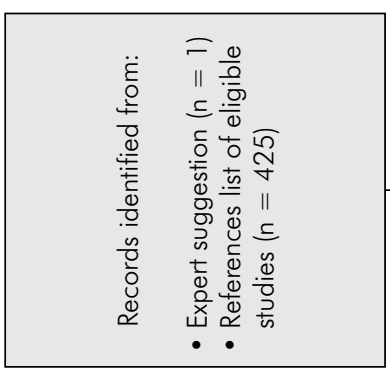

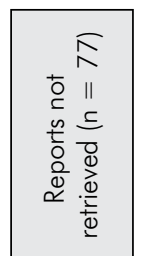
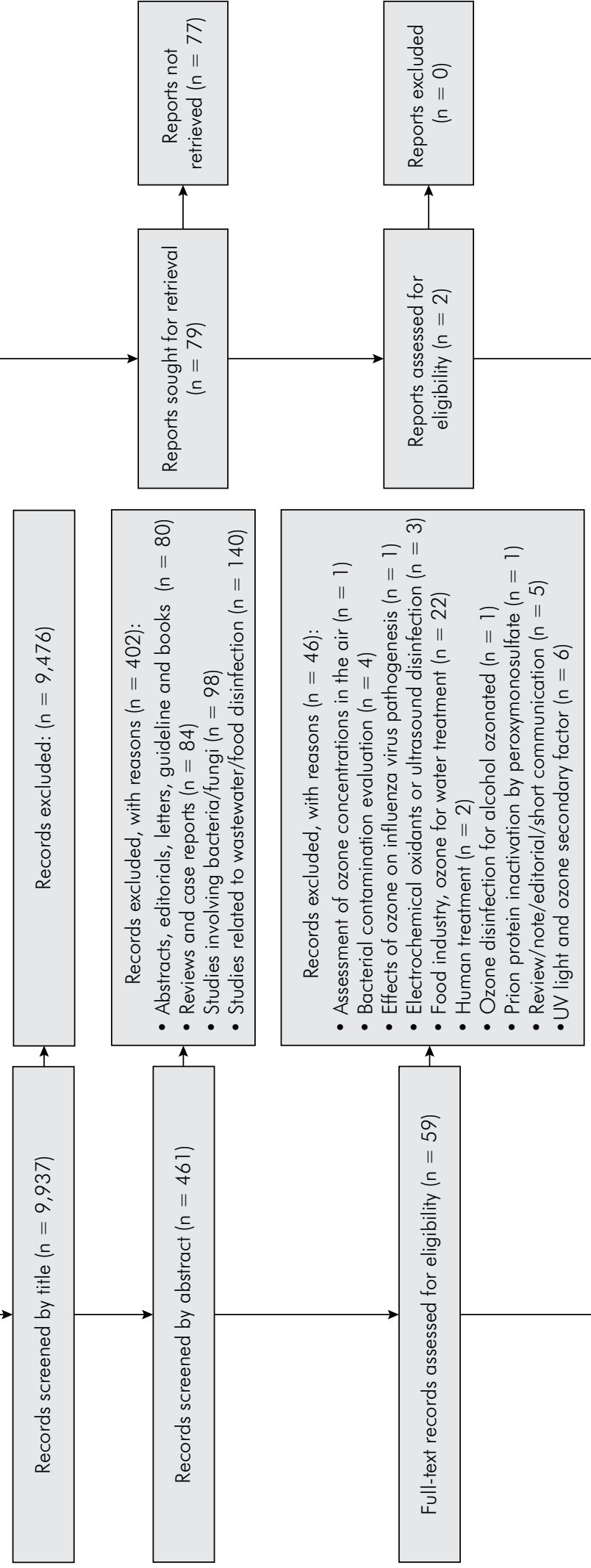

6u!ฺәәљร

рәрприі 
gas by adding aliquots of virus stock solutions in Petri dishes with the following sources: ${ }^{7,20-24}$ hospital textiles (fabrics, cloth, carpet, cotton), ${ }^{7,25,26}$ N95, PFF2 masks and respirators ${ }^{27,28}$; stainless steel disks ${ }^{7,29}$ or plastics. ${ }^{24,30}$ Only 3 studies ${ }^{31-33}$ used aerosol generators to simulate virus spread in the environment. Ozone application was considered efficient in reducing virus infectivity or virus integrity in $12(80 \%)$ of the 15 included articles (Table 2).

\section{Virus type}

The effect of ozone application was investigated on several viruses, including hepatitis $\mathrm{B}^{26}$ influenza $\mathrm{H} 1 \mathrm{~N} 1,{ }^{28} \mathrm{H} 3 \mathrm{~N} 2,{ }^{7}$ human respiratory syncytial RSV, ${ }^{28}$ lentiviral vector, ${ }^{33}$ human coronavirus HCoV-229E, ${ }^{27}$ murine norovirus, ${ }^{7,20,31}$ feline calicivirus, ${ }^{7,20,25,29}$ phages $\phi 6$ and $\phi X 174,{ }^{21,31,32}$ MS2 bacteriophages, ${ }^{21,31,32}$ phage PR772, ${ }^{31}$ twist synthetic SARS-CoV-2 RNA, ${ }^{30}$ Theiler's murine encephalomyelitis virus (TMEV), Reo type 3 virus (RV) and murine hepatitis virus (MHV), ${ }^{24}$ phage $\mathrm{T} 7,{ }^{21,32}$ herpes simplex virus, ${ }^{22,25}$ rhinovirus, ${ }^{7}$ adenovirus types 3 and 11,7 sindbis virus (SINV) ${ }^{7}$, yellow fever virus $(\mathrm{YFV})^{7}$, vesicular stomatitis virus $(\mathrm{VSV})^{7}$, poliovirus (PV vaccine strain) ${ }^{7}, 7$ vaccinia virus $(\mathrm{VV})^{7}$ and enterovirus $71^{23}$. Ozone gas was ineffective in hepatitis $\mathrm{B}^{26}$, lentiviral vector ${ }^{33}$ and enterovirus $71^{23}$ inactivation.

All of the studies included in this scoping review published in 2020 and 2021 27,28,30,31,33 focused on viral strains similar to SARS-CoV2. The authors described the following viruses as biosafe substitutes for SARSCoV-2: lentiviral vector, ${ }^{33} \mathrm{HCoV}-229 \mathrm{E},{ }^{27}$ influenza A virus (IAV; strain A/WSN/33) and human respiratory syncytial virus (RSV; strain A2). ${ }^{28}$ Three of these studies ${ }^{28,30,31}$ reported good results of virus inactivation after ozone exposure for at least 40 minutes.

\section{Ozone application}

Standardization of the unit of measurement used to assess the ozone concentration in ppm was obtained using the formula $1 \mathrm{ppmv}=0.002 \mathrm{mcg} / \mathrm{ml}$ for conversion, as suggested by Bocci (2011). ${ }^{34}$

Different types of equipment were used for ozonation, all of which use oxygen from the air as the source; an exception was Tseng and $\mathrm{Li}^{21,32}$ in which pure oxygen was the source used to feed the ozone generator OZIPCS-V/SW (Ozotech Inc., Yreka, USA). The devices produce ozone through electrical discharges or through plasma (Table 3). Five studies evaluated the effect of low ozone concentrations (<1.3 ppm), ${ }^{21,22,23,31,32}$ and two of them ${ }^{31,32}$ used aerosol generators to simulate virus spread. Considering the results of these studies, 40 minutes of ozone application with high $\mathrm{RH}$ $(85 \%)$ was most effective. Two studies showed that increased exposure time (44 minutes ${ }^{21}$ to $180 \mathrm{~min}^{22}$ ) was required when using low ozone concentrations for virus inactivation. One study ${ }^{23}$ demonstrated that a low ozone concentration $(<1.3 \mathrm{ppm})$ was not effective in reducing virus survival.

Most of the experiments ${ }^{20,21,24,27,28,30,31,32}$ utilized high ozone concentrations and were carried out in chambers and cabinets to avoid ozone leakage. One study demonstrated that ozone cannons were not efficient for disinfecting the surfaces of ambulances. ${ }^{33}$ The efficacy of ozone gas in an office, a laboratory, a hotel room and a cruise liner cabin was also tested. ${ }^{7,25}$ Overall, the variation in ozonation protocols among the studies did not allow direct comparison of results.

\section{Relative humidity ( $\mathrm{RH}$ )}

Ten articles reported $\mathrm{RH}$ during the tests. ${ }^{720-24,28,31,32,33}$ Among them, eight evaluated the influence of $\mathrm{RH}$ on virus degradation and/or virus infectivity. $7,21,24,25,28,29,31,32$ The results of these experiments controlling $\mathrm{RH}$ demonstrated that $\mathrm{RH}$ plays a key role in ozone reactivity, and in most studies, the optimum efficacy of ozone treatment was achieved under high RH (> 50\%). All of these studies reported a positive effect of elevated RH on the overall efficacy of ozone treatment.

\section{Industry sponsorship status}

The sponsorship status is shown in Table 4 . None of the studies reported any type of financial support from companies related to ozone-generating devices. In 7 studies, the authors declared no conflicts of interest. Two studies ${ }^{29,33}$ provided information by e-mail. Unclear information was observed in 8 of the selected studies, and in these cases, it was not possible to affirm sponsorship status even after attempts to contact the authors by email. 


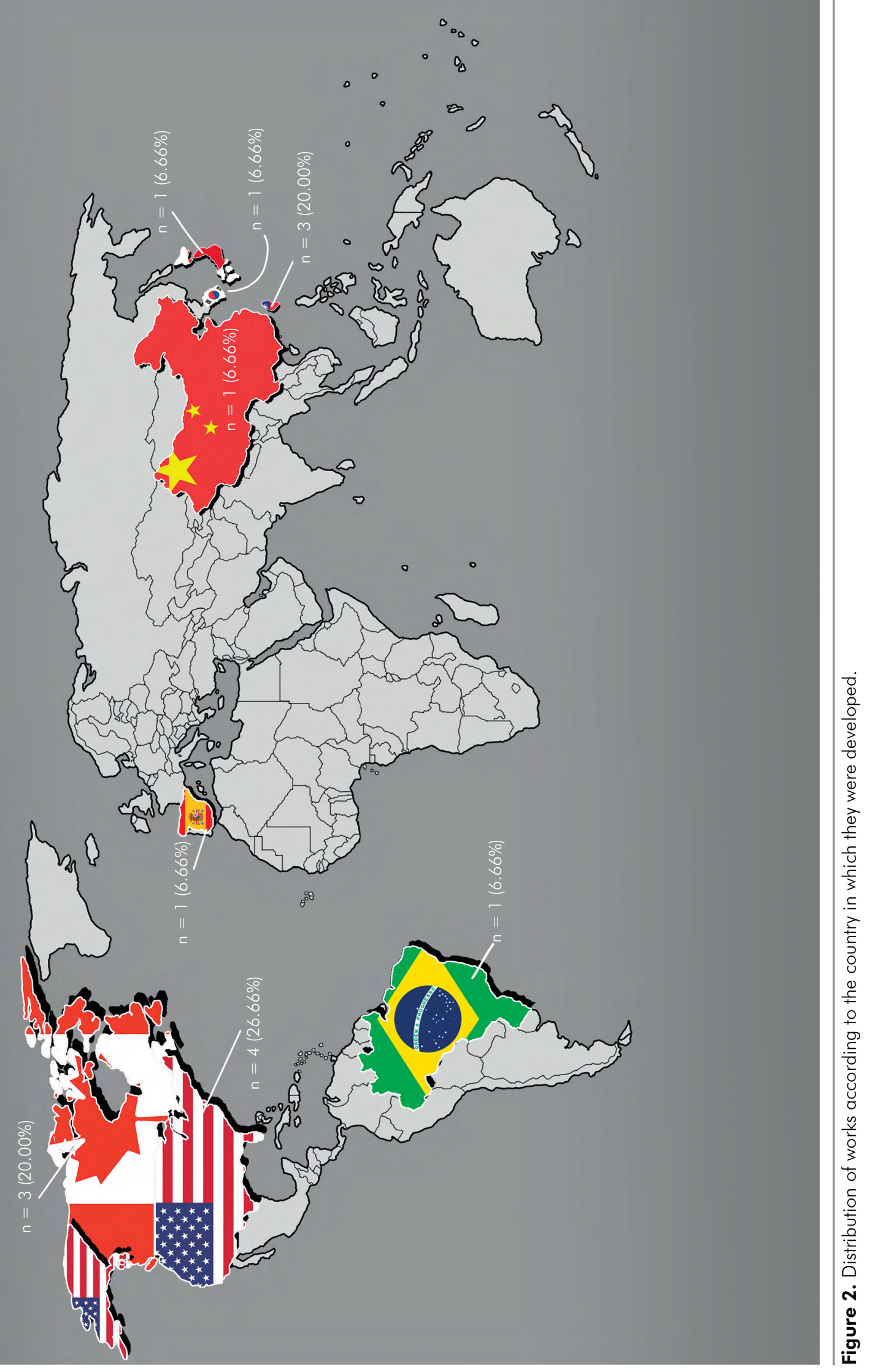


- Ozone disinfection for viruses with applications in healthcare environments: a scoping review

Table 2. Main characteristics of the eligible studies.

\begin{tabular}{|c|c|c|c|c|c|}
\hline Authors (year) & Virus type & Interventions & $\begin{array}{c}\text { Virus carrier/contact } \\
\text { surface }\end{array}$ & $\begin{array}{l}\text { Method of } \\
\text { assessing viral } \\
\text { inactivation }\end{array}$ & Main results \\
\hline \multirow{4}{*}{$\begin{array}{l}\text { Sato, Wananabe, } \\
\text { Miyata, } 1990^{24}\end{array}$} & TMEV & Ozone & $\begin{array}{l}\text { Dry phase: Lyophilized } \\
\text { virus samples in glass vials } \\
\text { were exposed to ozone }\end{array}$ & & \multirow{4}{*}{$\begin{array}{c}\text { Effective: More than } 100 \\
\text { ppm ozone and } 80 \% \text { of } \mathrm{RH} \\
\text { was strongly virucidal }\end{array}$} \\
\hline & HVJ & $\begin{array}{l}\text { Control (no } \\
\text { treatment) }\end{array}$ & $\begin{array}{l}\text { Liquid phase: A portion } \\
\text { of a hundredfold virus } \\
\text { sample in } 35-\mathrm{mm} \text { dishes }\end{array}$ & Plaque assay & \\
\hline & RV & & & & \\
\hline & MHV & & & & \\
\hline Tseng, Li, 2006 32 & $\begin{array}{c}\text { MS2 } \\
\phi 6 \\
\phi \times 174 \\
\text { T7 }\end{array}$ & $\begin{array}{l}\text { Ozone exposed } \\
\text { Ozone unexposed }\end{array}$ & $\begin{array}{l}\text { Virus stock solutions were } \\
\text { diluted in sterile, deionized } \\
\text { water for nebulization; } 3 \% \\
\text { gelatin plates were used } \\
\text { to collect virus-containing } \\
\text { aerosols before and after } \\
\text { ozone treatment. }\end{array}$ & Plaque assay & $\begin{array}{l}\text { Effective: The survival } \\
\text { fraction of all four viruses } \\
\text { decreased exponentially } \\
\text { with increasing ozone dose }\end{array}$ \\
\hline Hudson et al., $2007^{25}$ & $\begin{array}{l}\text { Norovirus and its } \\
\text { animal surrogate } \\
\text { feline calicivirus }\end{array}$ & Ozone exposed & $\begin{array}{l}\text { Virus samples were dried } \\
\text { on sterile plastic or other } \\
\text { surfaces (fabrics and } \\
\text { carpet, cotton tips, plastic) }\end{array}$ & RT-qPCR assay & $\begin{array}{l}\text { Effective: Substantial } \\
\text { inactivation of FCV and NV } \\
\text { samples was achieved, with } \\
\text { a comparable reduction in } \\
\text { RT-PCR values, indicating } \\
\text { that infectivity of both } \\
\text { viruses would be similarly } \\
\text { affected if it were possible to } \\
\text { assay for NV infectivity. }\end{array}$ \\
\hline Lin et al., $2007^{23}$ & Enterovirus 71 & $\begin{array}{c}\text { Control } \\
\text { (no treatment) }\end{array}$ & Virus stock in glass dishes & Plaque assay & $\begin{array}{l}\text { Ineffective: No statistically } \\
\text { significant differences in cell } \\
\text { viability were noted among } \\
\text { the control group and } 0.5 \\
\text { or } 1 \text { ppm ozone exposed } \\
\text { infected cells (Fig. } 3 B \text { ). The } \\
1.5 \text { or } 2 \text { ppm-exposed cells } \\
\text { had } 45-40 \% \text { viability. }\end{array}$ \\
\hline Tseng, Li, $2008^{21}$ & $\begin{array}{c}\text { MS2 } \\
\phi 6 \\
\phi \times 174 \\
\text { T7 }\end{array}$ & $\begin{array}{l}\text { Ozone exposed } \\
\text { Ozone unexposed }\end{array}$ & $\begin{array}{l}\text { A diluted culture of virus } \\
\text { stock solution was spread } \\
\text { on the surface of gelatin- } \\
\text { based medium. }\end{array}$ & Plaque assay & $\begin{array}{l}\text { Effective: The survival } \\
\text { fraction of all four viruses } \\
\text { decreased exponentially } \\
\text { with increasing ozone dose }\end{array}$ \\
\hline Hudson et al., $2009^{7}$ & $\begin{array}{c}\text { Influenza } \\
\text { HSV } \\
\text { Rhinovirus } \\
\text { Adenovirus } \\
\text { Mouse coronavirus } \\
\text { Sindbis virus } \\
\text { Yellow fever virus } \\
\text { Vesicular stomatitis } \\
\text { virus } \\
\text { Poliovirus } \\
\text { Vaccinia virus }\end{array}$ & $\begin{array}{l}\text { Ozone exposed } \\
\text { Ozone unexposed }\end{array}$ & $\begin{array}{l}\text { Aliquots of virus, diluted } \\
\text { when necessary in PBS, } \\
\text { were spotted onto glass } \\
\text { slides, stainless steel } \\
\text { circular disks, and pieces } \\
\text { of fabric and cotton. }\end{array}$ & Plaque assays & $\begin{array}{l}\text { Effective: All viruses tested, } \\
\text { showed similar kinetics of } \\
\text { virus inactivation on three } \\
\text { hard surfaces, plastic, glass } \\
\text { and stainless steel. The } \\
\text { combination of ozone gas } \\
\text { plus high RH consistently } \\
\text { yielded substantial } \\
\text { inactivation. }\end{array}$ \\
\hline $\begin{array}{l}\text { Cannon, Kotwal, } \\
\text { Wang, } 2013^{20}\end{array}$ & $\begin{array}{l}\text { Murine norovirus } \\
\qquad(\mathrm{MNV}-1)\end{array}$ & Ozone & $\begin{array}{l}\text { FCV or MNV-1 stocks were } \\
\text { spread uniformly onto glass } \\
\text { Petri dishes using a cell } \\
\text { scraper. One uninoculated } \\
\text { Petri dish was also included } \\
\text { in each experimental } \\
\text { replicate and served as a } \\
\text { negative control. }\end{array}$ & Plaque assays & $\begin{array}{l}\text { Effective: exposure of two } \\
\text { norovirus surrogates to } 20 \\
\text { ppm atmospheric ozone } \\
\text { for } 18 \text { min and } 80 \% \text { of RH } \\
\text { significantly reduced virus } \\
\text { infectivity on smooth glass } \\
\text { surfaces. }\end{array}$ \\
\hline
\end{tabular}




\begin{tabular}{|c|c|c|c|c|c|}
\hline \multicolumn{6}{|c|}{ Continuation } \\
\hline Authors (year) & Virus type & Interventions & $\begin{array}{l}\text { Virus carrier/contact } \\
\text { surface }\end{array}$ & $\begin{array}{l}\text { Method of } \\
\text { assessing viral } \\
\text { inactivation }\end{array}$ & Main results \\
\hline Petry et al., $2014^{22}$ & $\begin{array}{l}\text { Herpes Simplex } \\
\text { Virus } 1 \text { (HSV-1) } \\
\text { Bovine Herpes } \\
\text { Virus } 1 \text { (BoHV-1) }\end{array}$ & $\begin{array}{l}\text { Control (no } \\
\text { treatment) }\end{array}$ & $\begin{array}{l}\text { Aliquots of HSV- } 1 \text { and } \\
\text { BoHV- } 1 \text { propagated in } \\
\text { MDBK cells were added to } \\
\text { 35-mm Petri dishes. }\end{array}$ & Plaque assay & $\begin{array}{l}\text { Effective: Ozone promoted } \\
\text { a significant reduction of } \\
\text { more than } 90 \% \text { of viral } \\
\text { replication for both viruses } \\
\text { tested after } 3 \mathrm{~h} \text { of exposure. }\end{array}$ \\
\hline Guo et al., $2015^{26}$ & Hepatitis B & $\begin{array}{l}\text { Formaldehyde } \\
\text { oxidization } \\
\text { fumigation }\end{array}$ & $\begin{array}{l}\text { Serum was collected from } \\
\text { HBV-infected people with } \\
\text { a HBV DNA copy number } \\
\text { of 10-7 copies/ml. The } \\
\text { serum was diluted 10-fold } \\
\text { with sterile distilled water } \\
\text { and added to cloth. } \\
\text { Negative control groups } \\
\text { were composed of sterile } \\
\text { distilled water samples. }\end{array}$ & RT-qPCR & $\begin{array}{l}\text { Ineffective: Application of } \\
\text { ozone to disinfect HBV- } \\
\text { contaminated hospital linen } \\
\text { was ineffective. }\end{array}$ \\
\hline Nayak et al., $2018^{29}$ & FCV & $\begin{array}{l}\text { Control (no } \\
\text { treatment) }\end{array}$ & $\begin{array}{l}\text { Gas-phase: Sterile } \\
\text { stainless steel discs were } \\
\text { placed in wells of a } 24- \\
\text { well microtiter plates. The } \\
\text { surface of each disc was } \\
\text { spiked with } 15 \mu \text { l of FCV. }\end{array}$ & Plaque assay & $\begin{array}{l}\text { Effective: Gas-phase FCV } \\
\text { inactivation: Complete } \\
\text { inactivation was achieved within } \\
3 \text { min of treatment for the } \\
\text { humidified biosamples at } 1 \mathrm{~cm} \\
\text { distance from the discharge; } 1 \\
\mathrm{~cm} \text { is similar to } 40 \mathrm{~cm} \text {. Liquid- } \\
\text { phase FCV inactivation was also } \\
\text { effective: Significant reduction } \\
\text { in FCV titer was achieved by } \\
\text { treating sterile water for } 5 \text { min at } \\
1 \mathrm{~cm} \text { in dry air. }\end{array}$ \\
\hline $\begin{array}{l}\text { Cía et al., } 2020 \\
\text { (preprint) }^{33}\end{array}$ & Lentiviral vector & $\begin{array}{l}\text { UV-C light } \\
\text { Ozone }\end{array}$ & $\begin{array}{l}\text { Open Petri dishes containing } \\
\text { pSIN-GFP lentivector stock in } \\
\text { DMEM and containing dried } \\
\text { bacterial cultures inside an } \\
\text { ambulance. }\end{array}$ & $\begin{array}{l}\text { Fluorescence } \\
\text { microscopy } \\
\text { Flow cytometry } \\
\text { Plaque assays }\end{array}$ & $\begin{array}{l}\text { Ineffective: Ozone treatments } \\
\text { currently applied in emergency } \\
\text { vehicles in this study did not } \\
\text { significantly affect virus or } \\
\text { bacteria viability. }\end{array}$ \\
\hline $\begin{array}{l}\text { Blanchard et al., } 2020 \\
\text { (preprint) }^{28}\end{array}$ & $\begin{array}{c}\text { Influenza A } \\
\text { Human respiratory } \\
\text { syncytial }\end{array}$ & $70 \%$ ethanol & $\begin{array}{l}\text { Virus solutions in growth } \\
\text { medium were deposited } \\
\text { by pipette onto pieces of } \\
\text { each candidate material: } \\
\text { cloth face masks, Tyvek } \\
\text { (spun high-density } \\
\text { polyethylene) fabric used } \\
\text { in disposable gowns } \\
\text { and PAPR (powered air } \\
\text { purifying respirator) hoods, } \\
\text { and N95 respirators. } \\
\text { Uninoculated samples of } \\
\text { each material served as a } \\
\text { negative control. }\end{array}$ & Plaque assay & $\begin{array}{l}\text { Effective: Ozone treatment } \\
\text { at } 20 \text { ppm or greater, } 70 \% \\
\text { or greater RH at room } \\
\text { temperature, and for at least } \\
40 \text { minutes should reliably } \\
\text { inactivate enveloped viruses } \\
\text { on a variety of materials } \\
\text { used for medical PPE. }\end{array}$ \\
\hline \multirow[t]{2}{*}{ Dubuis et al., $2020^{31}$} & $\phi \times 174$ & Ozone & \multirow[t]{2}{*}{$\begin{array}{l}\text { The virus buffer was } \\
\text { placed in an aerosol } \\
\text { generator and nebulized } \\
\text { for } 10 \text { minutes. }\end{array}$} & \multirow[t]{2}{*}{$\mathrm{qPCR}$} & $\begin{array}{l}\text { Effective: } 40 \text { minutes and } \\
55 \% \text { of } \mathrm{RH} \text { of exposure was } \\
\text { required for } \phi \times 174 \text { and } \\
\text { MS2 inactivation. } \\
10 \text { minutes and } 85 \% \text { RH for } \\
\phi \times 174, \text { PR772 and MS2. } \phi 6 \\
\text { and MNV- } 1 \text { viruses showed } \\
\text { inactivation levels of at least } \\
\text { two orders of magnitude } \\
\text { after } 40 \text { minutes. }\end{array}$ \\
\hline & $\begin{array}{l}\text { PR772 } \\
\text { MS2 } \\
\text { MNV-1 }\end{array}$ & & & & \\
\hline
\end{tabular}




\begin{tabular}{|c|c|c|c|c|c|}
\hline Authors (year) & Virus type & Interventions & $\begin{array}{c}\text { Virus carrier/contact } \\
\text { surface }\end{array}$ & $\begin{array}{l}\text { Method of } \\
\text { assessing viral } \\
\text { inactivation }\end{array}$ & Main results \\
\hline Lee et al., $2021^{27}$ & $\begin{array}{c}\text { Human } \\
\text { coronavirus HCoV- } \\
229 \mathrm{E}\end{array}$ & Ozone & $\begin{array}{l}\text { HCoV-229E culture was } \\
\text { added to face masks. }\end{array}$ & Plaque assays & $\begin{array}{l}\text { Effective: When face masks } \\
\text { experimentally contaminated } \\
\text { with a human coronavirus } \\
\text { (HCoV-229E) as a surrogate } \\
\text { were exposed to ozone gas } \\
\text { (approximately } 120 \text { ppm) } \\
\text { produced by the plasma } \\
\text { generator for either } 1 \text { or } 5 \\
\text { min, the virus lost infectivity. }\end{array}$ \\
\hline $\begin{array}{l}\text { Westover et al., } 2020 \\
\text { (preprint) }^{30}\end{array}$ & $\begin{array}{c}\text { Twist Synthetic } \\
\text { SARS-CoV-2 RNA } \\
\text { Control } 2\end{array}$ & $\begin{array}{l}\text { Control (no } \\
\text { treatment) }\end{array}$ & $\begin{array}{l}\text { Aliquots of Twist Synthetic } \\
\text { SARS-CoV-2 RNA were } \\
\text { added to open tubes in } \\
\text { the Sani Sport Supreme. }\end{array}$ & qPCR $r$ & $\begin{array}{l}\text { Effective: Synthetic SARS- } \\
\text { CoV-2 RNA was shown } \\
\text { to undergo significant } \\
\text { degradation for } 1 \mathrm{hr} \text { under } \\
\text { ozone treatment. Ozone- } \\
\text { treated samples exhibited } \\
65.13 \%, 25.82 \%, 11.24 \% \text {, } \\
12.46 \% \text { and } 6.16 \% \text { of RNA } \\
\text { remaining for } 30 \text { mins, } 1 \text { hr, } \\
2 \text { hr, } 3 \text { hr, and } 4 \text { hrs. RNAse- } \\
\text { treated samples showed } \\
\text { complete degradation. }\end{array}$ \\
\hline
\end{tabular}

\section{Discussion}

Our search identified articles with sufficient evidence for a survey of the effectiveness of ozone gas for inactivating some vehicle-borne viruses. This scoping review provides useful insight for the design, implementation, and effectiveness of ozone gas applications for virus inactivation on surfaces and objects under different conditions, including health services.

The outbreak of SARS-CoV-2 has reinforced the need to develop methods for disinfection, especially those applicable to health care environments. Several methods have been proposed, such as aerosolized hydrogen peroxide, $\mathrm{H}_{2} \mathrm{O}_{2}$ vapor, ultraviolet $\mathrm{C}$ light, pulsed xenon, and gaseous ozone. ${ }^{35}$ Among these, the efficient penetrability of a gas allows the decontamination of inaccessible locations and disinfection of much more than just surfaces, such as crevices, fixtures, and the undersides of furniture. In addition, air treatment should be considered to reduce the infectivity of airborne diseases. ${ }^{7}$ Thus, several devices that generate ozone for this purpose have been developed in recent months.

To narrow the search to microorganisms (or their surrogates) commonly transmitted in health care environments, vehicle-borne and airborne viruses were considered in this scoping review. Thus, studies involving sewage treatment, decontamination in the food and agriculture fields were excluded. Disinfection with ozone gas was effective against many types of viruses with or without an envelope, and decreased virus infectivity was reported in most of the studies $(80 \%)$. Gaseous ozone was efficient in reducing the infectivity of several common viruses acquired in hospital settings, such as norovirus, ${ }^{7,20,31}$ influenza, 28 and RSV. ${ }^{28}$

Such effectiveness has also been recently demonstrated for SARS-COV2 biosafe surrogate viruses. As handling of SARS-CoV-2 requires biosafety level (BSL) 3 facilities, ${ }^{36}$ surrounding viruses are commonly used to facilitate research. Twist synthetic SARS-CoV-2 RNA, ${ }^{30} \mathrm{HCoV}-229 \mathrm{E},{ }^{27}$ influenza A virus (IAV; strain A/WSN/33) and human respiratory syncytial virus (RSV; strain A2) ${ }^{28}$ are considered biosafe substitutes for SARS-COV-2 due to their similarity in form, structure and function. Although the analyzed studies employed surrogates for SARS-CoV-2, some ${ }^{21,24,32}$ published before the pandemic showed the efficiency of ozone gas application against viruses that are actually considered surrogates for SARS-CoV-2, such as MHV (mouse hepatitis virus) 
Table 3. Ozone application parameters.

\begin{tabular}{|c|c|c|c|c|c|}
\hline Authors (year) & Ozonation method & $\begin{array}{c}\text { Ozone } \\
\text { concentration (ppm) }\end{array}$ & $\begin{array}{l}\text { Temperature } \\
\left({ }^{\circ} \mathrm{C}\right)\end{array}$ & $\begin{array}{l}\text { Humidity } \\
(\%)\end{array}$ & $\begin{array}{l}\text { Time evaluated } \\
\text { (min) }\end{array}$ \\
\hline $\begin{array}{l}\text { Sato, Watanabe, } \\
\text { Miyata, } 1990^{24}\end{array}$ & $\begin{array}{l}\text { Ozone Generator (Elios Ozonizer, Shinryo. } \\
\text { Reinetsu. Co. Tokyo. Japan) }\end{array}$ & $\begin{array}{l}\text { HJV samples: } 200 \\
\text { TMEV samples: } 100 \\
\text { and } 200\end{array}$ & $22-25$ & $50-90$ & $30 \mathrm{mi}$ \\
\hline Tseng; Li, $2006^{32}$ & $\begin{array}{c}\text { Ozone generator (OZ1PCS-V/SW, Ozotech Inc., } \\
\text { Yreka, CA) }\end{array}$ & $0.1-10$ & $25-28$ & $55-85$ & $\begin{array}{l}13.8 \mathrm{sec} \\
18.4 \mathrm{sec}\end{array}$ \\
\hline $\begin{array}{l}\text { Hudson et al., } \\
2007^{25}\end{array}$ & $\begin{array}{l}\text { Multiple corona discharge units (Viroforce 1000; } \\
\text { Viroforce Systems, Kelowna, BC, Canada) }\end{array}$ & $20-25$ & 23 & $\begin{array}{l}70 \text { in } \\
\text { excess }\end{array}$ & 20 \\
\hline Lin et al., $2007^{23}$ & Ozone Generator (Tenco, XV1043CA, Taiwan) & $0.5,1,1.5 ; 2$ & 25 & & 120 \\
\hline Tseng; Li, $2008^{21}$ & $\begin{array}{c}\text { Ozone generator (OZ1PCS-V/SW, Ozotech Inc., } \\
\text { Yreka, CA) }\end{array}$ & $0.6 ; 0.9 ; 1.2$ & $25-28$ & $55-85$ & $\begin{array}{c}5 \\
10 \\
15 \\
20 \\
40 \\
60 \\
90 \\
120\end{array}$ \\
\hline $\begin{array}{l}\text { Hudson et al., } \\
2009^{7}\end{array}$ & $\begin{array}{l}\text { Ozone generators (Treated Air Systems) for the } \\
\text { initial field trials } \\
\text { Multiple corona discharge units (Viroforce 1000; } \\
\text { Viroforce Systems, Kelowna, BC, Canada) }\end{array}$ & 25 & 20 & $\begin{aligned} & 40 \\
> & 90\end{aligned}$ & $\begin{array}{c}10(\mathrm{RH} \text { tests }> \\
90 \%) \\
60\end{array}$ \\
\hline $\begin{array}{l}\text { Cannon, Kotwal, } \\
\text { Wang, } 2013^{20}\end{array}$ & Ozone generator (ZONOsanitech, Alpharetta, GA). & 20 & $\begin{array}{l}\text { Room } \\
\text { temperature }\end{array}$ & 80 & 18 \\
\hline Petry et al., $2014^{22}$ & $\begin{array}{l}\text { Ozone generator (Brizzamar, Ronda Alta, } \\
\text { RS, Brazil) }\end{array}$ & $0.02-0.05$ & $26.2-29.2$ & $30-37$ & $\begin{array}{l}60 \\
120 \\
180\end{array}$ \\
\hline Guo et al., $2015^{26}$ & $\begin{array}{c}\text { Computer-controlled bed unit ozone sterilizer } \\
\text { (Kz-x-dL1, Guangdong Kangzhen Medical } \\
\text { Equipment Co. Ltd., Guang-dong province, } \\
\text { China) }\end{array}$ & $150^{*}$ & & & $\begin{array}{l}15 \\
30 \\
60 \\
80\end{array}$ \\
\hline Nayak et al., $2018^{29}$ & Dieletric barrier discharge & 20 & & & $\begin{array}{c}5 \\
20\end{array}$ \\
\hline Cía et al., $2020^{33}$ & Ozone generator (Industrial Global Supply S.L.) & Higher than 10 & & $37-48$ & $\begin{array}{l}10 \\
20\end{array}$ \\
\hline $\begin{array}{l}\text { Blanchard et al., } \\
2020^{28}\end{array}$ & $\begin{array}{c}\text { Global Ozone Decon-Zone 4201A Cabinet// } \\
\text { Global Ozone } \\
\text { OT-100 Trailer//Zono SC } 1 \text { Cabinet// } \\
\text { VirtuCLEAN } \\
\text { 2.0 Waterless CPAP Cleaning Pouch }\end{array}$ & Approximately 20 & $\begin{array}{l}\text { Room } \\
\text { temperature }\end{array}$ & $\begin{array}{c}40 \\
50-70 \\
80\end{array}$ & 320 \\
\hline Lee et al., $2020^{27}$ & Dieletric barrier discharge & Approximately 120 & 25 & -- & $\begin{array}{l}1 \\
5\end{array}$ \\
\hline $\begin{array}{l}\text { Dubuis et al., } \\
2020^{31}\end{array}$ & $\begin{array}{c}\text { Ozone generator (model EMO3-VTTL, EMO3, } \\
\text { Quebec City, CANADA) }\end{array}$ & $\begin{array}{l}\text { Phages: } 1.13 \pm \\
0.26 \\
\text { MNV-1: } 0.23 \pm \\
0.03\end{array}$ & & $55 \%$ & 40 \\
\hline $\begin{array}{l}\text { Westover et al., } \\
2020^{30}\end{array}$ & Ozone generator (Sani Sport Supreme) & 20 & & $85 \%$ & $\begin{array}{c}70 \\
30 \\
60 \\
120 \\
180 \\
240\end{array}$ \\
\hline
\end{tabular}

${ }^{*}$ Conversion $1 \mathrm{ppm}=0.002 \mathrm{mcg} / \mathrm{ml}$ 
Table 4. Sponsorship status of the studies.

\begin{tabular}{|c|c|c|c|}
\hline \multirow{2}{*}{ Authors (year) } & \multicolumn{3}{|c|}{ Sponsorship status } \\
\hline & Sponsored & Nonsponsored & Unclear \\
\hline $\begin{array}{l}\text { Sato, Wananabe, Miyata, } \\
1990^{24}\end{array}$ & & & $x$ \\
\hline Tseng, Li, $2006^{32}$ & & & $x$ \\
\hline Hudson et al., $2007^{25}$ & & & $x$ \\
\hline Lin et al., $2007^{23}$ & & & $x$ \\
\hline Tseng, Li, $2008^{21}$ & & & $x$ \\
\hline Hudson et al., $2009^{7}$ & & & $x$ \\
\hline $\begin{array}{l}\text { Cannon, Kotwal, Wang, } \\
2013^{20}\end{array}$ & & & $x$ \\
\hline Petry et al., $2014^{22}$ & & & $x$ \\
\hline Guo et al., $2015^{26}$ & & $x$ & \\
\hline Nayak et al., $2018^{29}$ & & $x$ & \\
\hline Cía et al., $2020^{33}$ & & $x$ & \\
\hline Blanchard et al., $2020^{28}$ & & $x$ & \\
\hline Dubuis et al., $2020^{31}$ & & $x$ & \\
\hline Lee et al., $2021^{27}$ & & $x$ & \\
\hline Westover et al., $2020^{30}$ & & $x$ & \\
\hline
\end{tabular}

and Phi6. ${ }^{4}$ Dubuis et al. ${ }^{31}$ demonstrated the effect of ozone as a disinfectant against multiple phages with different features to represent a broad range of eukaryotic viruses and their resistance when airborne and when exposed to disinfecting agents.

Nevertheless, three studies ${ }^{23,26,33}$ showed evidence that gaseous ozone was ineffective against specific types of viruses. For example, Cía et al. ${ }^{33}$ found that gaseous ozone treatments applied for emergency vehicles do not significantly affect virus viability; in this study, the effect of an ozone cannon device (10 ppm) against HIV-1-derived lentivectors inside an emergency vehicle was investigated. Guo et al. ${ }^{26}$ demonstrated that the application of ozone (140 ppm) to disinfect HBV-contaminated hospital linen was also ineffective, even when the disinfection time was prolonged to $80 \mathrm{~min}$. Lin et al. ${ }^{23}$ observed approximately $85 \%$ viability for cells exposed to 1.5 and 2 ppm ozone, and increasing the ozone concentration to 2.5 and 3 ppm achieved 40 and $50 \%$ cell mortality with 1 and $2 \mathrm{~h}$ exposure, respectively. Interestingly, the study involving the emergency vehicle ${ }^{33}$ used low RH $(37 \%-48 \%)$, but the other studies ${ }^{23,26}$ did not mention the $\mathrm{RH}$ of the experiment. The literature is clear regarding the role $\mathrm{RH}$ plays in the disinfection process using ozone. ${ }^{37}$ Blanchard et al. ${ }^{28}$ suggested that humidity may act through two mechanisms: (a) water may promote the generation of highly reactive hydroxyl radicals from ozone, and (b) greater humidity may facilitate ozone interacting with surface-bound species, such as by diffusion, to reach viruses. Therefore, the evidence of this scoping review found optimum efficacy of ozone treatment under high $\mathrm{RH}(>50 \%)$.

It is not appropriate to determine the effectiveness of a specific disinfection method by relying only on the resistance of the virus being analyzed. Indeed, each virus has different tolerances for various protocols. ${ }^{31}$ The ozone generation mechanism may also affect results. Ozone is obtained by transforming oxygen via electrical discharges, and there are three different systems exist for generating ozone gas: ultraviolet, plasma or corona systems. The ozone gas produced by ultraviolet light is obtained at low concentrations and acts as a secondary product complementary to the UV effect. The cold plasma system is very commonly used to purify water and air in public environments, and the corona discharge system, which is mainly used in health care settings, produces ozone more effectively and at a greater concentration. The mechanism of artificial ozone production occurs through electrochemical discharge known as the corona effect. Another advantage of this method is that it can be applied in water. ${ }^{38}$

The type of material or virus carrier applied varied among the studies, which did not allow for direct comparisons. The experimental setup and methodology used most commonly were virus stock spread on glass dishes, $7,20,22,23,24,33$ stainless steel disks, ${ }^{29}$ or gelatin medium ${ }^{21}$ and allowed to dry before ozone exposure. In general, disinfection of hospital equipment was the main focus after the SARS-COV2 outbreak. Disinfection of face masks, ${ }^{27,28}$ Tyvek (spun high-density polyethylene) fabric used in disposable gowns and PAPR (powered air-purifying respirator) hoods ${ }^{28}, \mathrm{~N} 95$ respirators, ${ }^{28}$ and samples of fabrics and carpet ${ }^{25}$ has been demonstrated. No substantial loss of filtration performance was found for ozone-treated masks ${ }^{27,28}$. Thus, in times of shortages, ozone treatment has proven to be an effective method for disinfecting personal protective equipment (PPE) for safe reuse. 
Viral quantification can be performed by the standard plaque assay method ${ }^{39}$ or viral titration for quantitative assay of the infectivity of virus recovered in monolayer cells of selected bacterial strains as hosts $^{23,40,41,42}$. RT-PCR is another quantification method that measures a defined sequence of the viral genome; as one would expect this method be more resistant to the damaging effects of ozone gas than infectivity, it probably underestimates the effectiveness of antiviral agents. Thus, it would be worthwhile to use two methods to analyze infectivity and viral degradation. In fact, the importance of these two methods of quantification was clear in the study of Lee et al. ${ }^{27}$ In this experiment, no viable $\mathrm{HCoV}-22 \mathrm{E}$ was recovered from face masks, and the virus was shown to lose infectivity in a human cell line (MRC-5) when exposed for a short period of time ( $1 \mathrm{~min}$ ) to ozone gas produced by a DBD plasma generator. However, the short exposure may not fully degrade the viral RNA because no significant difference in the amount of amplifiable RNAs between treated and untreated masks was observed. These results suggest that loss of infectivity could be due to damage to the viral envelope or envelope proteins, resulting in failure of the virus to attach to host cells.

The concentration of ozone required for efficacy also depends on the exposure time. The ozone concentration in the majority of the studies included in this review was several magnitudes higher than the exposure limits defined for Occupational Safety and Health regulations. For this reason, most of them were performed in a proper chamber or cabinet. The major disadvantage of the use of ozone is its potential toxicity at high concentrations; thus, precautions must be taken to avoid such exposure. In general, limits for workers are $<0.1 \mathrm{ppm}$ or $0.2 \mathrm{mg} / \mathrm{m}^{3}$ on average over $8 \mathrm{~h},<0.3 \mathrm{ppm}$ if the exposure time is only 15 $\mathrm{min}$; PPE is needed if the concentration is $>0.3 \mathrm{ppm}$. Challenges can be overcome by ensuring that the area is emptied of staff, closed off, and sealed. ${ }^{37}$ Ozone gas decays quickly to oxygen, with a half-life of approximately $20 \mathrm{~min}$. Another plausible option is the use of a catalytic converter (scrubber) near closed doors and inside them to accelerate ozone degradation and avoid leakage. Ozone concentrations below 0.1 ppm may be feasible for treating air inside unoccupied hospital rooms. ${ }^{31}$ More studies using lower concentrations but longer exposure periods to treat air in an unsealed unoccupied room should be performed to avoid worker and patient toxicity.

It should also be noted that most studies used ozone generators with industrial and domestic applications that obtain ozone from ambient air. Such equipment produces ozone but can also release other compounds derived from gases present in the atmosphere. Similar to ozone, the concentration of these contaminants in air varies according to temperature and air humidity. ${ }^{43,44}$ It is important to note that there is a possibility that such devices produce ozone concentrations higher or lower than those indicated by the manufacturer, which can also affect results. Thus, such rates and concentrations should be measured. ${ }^{45}$ Devices that use sterile oxygen for ozone generation, on the other hand, will not only provide byproducts free of such gases and compounds but will also have effective flow regulation. ${ }^{43}$ Future studies should be carried out to detect compounds generated by domestic and industrial generators, as well as the exact concentrations of the generated ozone in both systems. Comparative studies between generators that use ambient air and medicinal oxygen should also be performed.

Another limitation was possible sponsorship bias present among the selected studies. Most of the studies ${ }^{7,20-25,32}$ were classified as unclear with regard to sponsorship status. Authors did not state whether they received any type of funding or provision of devices from companies related to ozone generators, and they did not mention no conflict of interest. Sponsorship from companies, mainly in studies evaluating specific devices or products, might lead to bias. Risks of publication, reporting and selection biases as well as publication of selected results have been associated with industry sponsorship. ${ }^{18,46}$ Therefore, the results of this study should be interpreted with caution, and future studies should be performed to assess the presence of sponsorship bias among studies evaluating the effectiveness of ozone generators as disinfecting agents.

\section{Conclusion}

Our findings suggest that ozone should be considered as an effective method to decrease the infectivity of several viruses commonly acquired 
inside hospitals and other healthcare environments. This scoping review provides direction for a future systematic review to investigate not only the effectiveness but also a better protocol for the use of ozone as a disinfectant or sterilization method for environments and surfaces, thus contributing to disease prevention in both emergency situations and pandemics, as well as in daily routines.

\section{Acknowledgements}

This study was funded by the Coordenação de Aperfeiçoamento de Pessoal de Nível Superior - Brazil (CAPES) - Finance code 001 and by the Ministry of Science, Technology, Innovation and Communications, Ministry of Health of Brazil and National Council for Scientific and Technological Development (CNPq; award numbers: 307808/2018-1 and 401612/2020-1).

\section{References}

1. Noorimotlagh Z, Mirzaee SA, Jaafarzadeh N, Maleki M, Kalvandi G, Karami C. A systematic review of emerging human coronavirus (SARS-CoV-2) outbreak: focus on disinfection methods, environmental survival, and control and prevention strategies. Environ Sci Pollut Res Int. 2021 Jan;28(1):1-15. https://doi.org/10.1007/s11356-020-11060-z

2. Fernández-Cuadros ME, Albaladejo-Florín MJ, Álava-Rabasa S, Usandizaga-Elio I, Martinez-Quintanilla Jimenez D, Peña-Lora D, et al. Effect of Rectal Ozone (O3) in severe COVID-19 pneumonia: preliminary results. SN Compr Clin Med. 2020 Aug;2(9):1-9. https://doi.org/10.1007/s42399-020-00374-1

3. Singhal T. A review of Coronavirus disease-2019 (COVID-19). Indian J Pediatr. 2020 Apr;87(4):281-6. https://doi.org/10.1007/s12098-020-03263-6

4. Castaño N, Cordts SC, Kurosu Jalil M, Zhang KS, Koppaka S, Bick AD, et al. Fomite transmission, physicochemical origin of virus-surface interactions, and disinfection strategies for enveloped viruses with applications to SARS-CoV-2. ACS Omega. 2021 Mar;6(10):6509-27. https://doi.org/10.1021/acsomega.0c06335

5. Tellier R, Li Y, Cowling BJ, Tang JW. Recognition of aerosol transmission of infectious agents: a commentary. BMC Infect Dis. 2019 Jan;19(1):101. https://doi.org/10.1186/s12879-019-3707-y

6. Zhang Q, Jenkins PL. Evaluation of ozone emissions and exposures from consumer products and home appliances. Indoor Air. 2017 Mar;27(2):386-97. https://doi.org/10.1111/ina.12307

7. Hudson JB, Sharma M, Vimalanathan S. Development of a practical method for using ozone gas as a virus decontaminating agent. Ozone Sci Eng. 2009;31(3):216-23. https://doi.org/10.1080/01919510902747969

8. Bocci VA. Scientific and medical aspects of ozone therapy: state of the art. Arch Med Res. 2006 May;37(4):425-35. https://doi.org/10.1016/j.arcmed.2005.08.006

9. Gomes J, Matos A, Gmurek M, Quinta-Ferreira RM, Martins RC. Ozone and photocatalytic processes for pathogens removal from water: a review. Catalysts. 2019;9(1):46. https://doi.org/10.3390/catal9010046

10. Wolf C, von Gunten U, Kohn T. Kinetics of inactivation of waterborne enteric viruses by ozone. Environ Sci Technol. 2018 Feb;52(4):2170-7. https://doi.org/10.1021/acs.est.7b05111

11. Cattel F, Giordano S, Bertiond C, Lupia T, Corcione S, Scaldaferri M, et al. Ozone therapy in COVID-19: a narrative review. Virus Res. 2021 Jan;291:198207. https://doi.org/10.1016/j.virusres.2020.198207

12. Yao M, Zhang L, Ma J, Zhou L. On airborne transmission and control of SARS-Cov-2. Sci Total Environ. 2020 Aug;731:139-78. https://doi.org/10.1016/j.scitotenv.2020.139178

13. Niu Y, Cai J, Xia Y, Yu H, Chen R, Lin Z, et al. Estimation of personal ozone exposure using ambient concentrations and influencing factors. Environ Int. 2018 Aug;117:237-42. https://doi.org/10.1016/i.envint.2018.05.017

14. Moher D, Shamseer L, Clarke M, Ghersi D, Liberati A, Petticrew M, et al. Preferred reporting items for systematic review and meta-analysis protocols (PRISMA-P) 2015 statement. Rev Esp Nutr Humana y Diet. 2016;20(2):148-60. https://doi.org/10.1186/2046-4053-4-1

15. Tricco AC, Lillie E, Zarin W, O'Brien KK, Colquhoun H, Levac D, et al. PRISMA extension for scoping reviews (PRISMA-ScR): checklist and explanation. Ann Intern Med. 2018 Oct;169(7):467-73. https://doi.org/10.7326/M18-0850

16. Aromataris E, Munn Z, editors. JBI manual for evidence synthesis. JBI; 2020. Chapter 11: Peters M, Godfrey C, Mclnerney P, Munn Z, Trico A, Khalil H. Scoping reviews; p. 406-51.

17. Arksey H, O'Malley L. Scoping studies: towards a methodological framework. Int J Soc Res Methodol. 2005;8(1):19-32. https://doi.org/10.1080/1364557032000119616

18. Del Parigi A. Industry funded clinical trials: bias and quality. Curr Med Res Opin. 2012 Jan;28(1):23-5. https://doi.org/10.1185/03007995.2011.628651 
Irie MS, Dietrich L, Souza GL, Soares PBF, Moura CCG, Silva GR, et al.

19. Santos MB, Agostini BA, Moraes RR, Schwendicke F, Sarkis-Onofre R. Industry sponsorship bias in clinical trials in implant dentistry: systematic review and meta-regression. J Clin Periodontol. 2019 Apr;46(4):510-9. https://doi.org/10.1111/icpe.13100

20. Cannon JL, Kotwal G, Wang Q. Inactivation of Norovirus Surrogates after Exposure to Atmospheric Ozone. Ozone Sci Eng. 2013;35(3):217-9. https://doi.org/10.1080/01919512.2013.771953

21. Tseng C, Li C. Inactivation of surface viruses by gaseous ozone. J Environ Health. 2008 Jun;70(10):56-62.

22. Petry G, Rossato LG, Nespolo J, Kreutz LC, Bertol CD. In Vitro inactivation of herpes virus by ozone. Ozone Sci Eng. 2014;36(3):249-52. https://doi.org/10.1080/01919512.2013.862165

23. Lin YC, Juan HC, Cheng YC. Ozone exposure in the culture medium inhibits enterovirus 71 virus replication and modulates cytokine production in rhabdomyosarcoma cells. Antiviral Res. 2007 Dec;76(3):241-51. https://doi.org/10.1016/i.antiviral.2007.07.004

24. Sato H, Wananabe Y, Miyata H. Virucidal effect of ozone treatment of laboratory animal viruses. Jikken Dobutsu. 1990 Apr;39(2):223-9. https://doi.org/10.1538/expanim1978.39.2_223

25. Hudson JB, Sharma M, Petric M. Inactivation of Norovirus by ozone gas in conditions relevant to healthcare. J Hosp Infect. 2007 May;66(1):40-5. https://doi.org/10.1016/i.jhin.2006.12.021

26. Guo D, Li Z, Jia B, Che X, Song T, Huang W. Comparison of the effects of formaldehyde and gaseous ozone on HBV-contaminated hospital quilts. Int J Clin Exp Med. 2015 Oct;8(10):19454-9.

27. Lee J, Bong C, Lim W, Bae PK, Abafogi AT, Baek SH, et al. Fast and easy disinfection of coronavirus-contaminated face masks using ozone gas produced by a dielectric barrier discharge plasma generator. Environ Sci Technol Lett. 2021 Feb;8(4):339-44. https://doi.org/10.1021/acs.estlett.1c00089

28. Blanchard EL, Lawrence JD, Noble JA, Xu M, Joo T, Ng NL, et al. Enveloped virus inactivation on personal protective equipment by exposure to ozone. MedRxiv. 2020 May. https://doi.org/10.1101/2020.05.23.20111435

29. Nayak G, Aboubakr HA, Goyal SM, Bruggeman PJ. Reactive species responsible for the inactivation of feline calicivirus by a two-dimensional array of integrated coaxial microhollow dielectric barrier discharges in air. Plasma Process Polym. 2018;15(1):1700119. https://doi.org/10.1002/ppap.201700119

30. Westover C, Rahmatulloev S, Danko D, O'Hara NB, Ounit R, Bezdan D, et al. Ozone treatment for elimination of bacteria and SARS-CoV-2 for medical environments. BioRxiv. 2020. https://doi.org/10.1101/420737

31. Dubuis ME, Dumont-Leblond N, Laliberté C, Veillette M, Turgeon N, Jean J, et al. Ozone efficacy for the control of airborne viruses: bacteriophage and norovirus models. PLoS One. 2020 Apr;15(4):e0231164. https://doi.org/10.1371/journal.pone.0231164

32. Tseng CC, Li CS. Ozone for inactivation of aerosolized bacteriophages. Aerosol Sci Technol. 2006;40(9):683-9. https://doi.org/10.1080/02786820600796590

33. Cía JB, Martínez BG, Montero AP, Kochan G, Escors D, Martinez JC, et al. Evaluation of the disinfecting capacity of ozone in emergency vehicles. MedRxiv. 2020 May. https://doi.org/10.1101/2020.05.24.20111666

34. Bocci V. Ozone: a new medical drug. 2nd. ed. Heidelberg: Springer Netherlands; 2011. https://doi.org/10.1007/978-90-481-9234-2

35. Scarano A, Inchingolo F, Lorusso F. Environmental disinfection of a dental clinic during the Covid-19 pandemic: a narrative insight. BioMed Res Int. 2020 Oct;2020:8896812. https://doi.org/10.1155/2020/8896812

36. World Health Organization. Laboratory biosafety guidance related to coronavirus disease (COVID-19). Geneva: World Health Organization; 2021 [cited 2021 Jan 28]. Available from: https://www.who.int/publications/i/item/WHO-WPE-GIH-2021.1

37. Blanco A, Ojembarrena FB, Clavo B, Negro C. Ozone potential to fight against SAR-COV-2 pandemic: facts and research needs. Environ Sci Pollut Res Int. 2021 Apr;28(13):16517-31. https://doi.org/10.1007/s11356-020-12036-9

38. Jiang B, Zheng J, Qiu S, Wu M, Zhang Q, Yan Z, et al. Review on electrical discharge plasma technology for wastewater remediation. Chem Eng J. 2014;236:348-68. https://doi.org/10.1016/i.cej.2013.09.090

39. Zhou Z, Zuber S, Cantergiani F, Sampers I, Devlieghere F, Uyttendaele M. Inactivation of foodborne pathogens and their surrogates on fresh and frozen strawberries using gaseous ozone. Front Sustain Food Syst. 2018;2:51. https://doi.org/10.3389/fsufs.2018.00051

40. Predmore A, Sanglay G, Li J, Lee K. Control of human norovirus surrogates in fresh foods by gaseous ozone and a proposed mechanism of inactivation. Food Microbiol. 2015 Sep;50:118-25. https://doi.org/10.1016/i.fm.2015.04.004

41. Hiroshi T, Miei S, Kousuke I, Yoshiaki M, Tanaka H, Sakurai M, et al. Inactivation of influenza virus by ozone gas. IHI Eng Rev. 2009;42(2):108-11.

42. Brié A, Boudaud N, Mssihid A, Loutreul J, Bertrand I, Gantzer C. Inactivation of murine norovirus and hepatites: a virus on fresh raspberries by gaseous ozone treatment. Food Microbiol. 2018 Apr;70:1-6. https://doi.org/10.1016/i.fm.2017.08.010

43. Takaki K, Hatanaka Y, Arima K, Mukaigawa S, Fujiwara T. Influence of electrode configuration on ozone synthesis and microdischarge property in dielectric barrier discharge reactor. Vacuum. 2008;83(1):128-32. https://doi.org/10.1016/i.vacuum.2008.03.047

44. Choudhury B, Portugal S, Mastanaiah N, Johnson JA, Roy S. Inactivation of Pseudomonas aeruginosa and Methicillin-resistant Staphylococcus aureus in an open water system with ozone generated by a compact, atmospheric DBD plasma reactor. Sci Rep. 2018 Dec;8(1):17573. https://doi.org/10.1038/s41598-018-36003-0 
- Ozone disinfection for viruses with applications in healthcare environments: a scoping review

45. Sánchez GM, Tapia A, Mariño R, Sabbah F. Non-recommended routes of application in ozone therapy, a critical review. Rev Española Ozonoterapia. 2018;8(1):19-35.

46. Boutron I, Dutton S, Ravaud P, Altman DG. Reporting and interpretation of randomized controlled trials with statistically nonsignificant results for primary outcomes. JAMA. 2010 May;303(20):2058-64. https://doi.org/10.1001/jama.2010.651 